\title{
TANGGUNG JAWAB RUMAH SAKIT TERHADAP TENAGA MEDIS DALAM KESELAMATAN DAN KESEHATAN KERJA AKIBAT PELAYANAN MEDIS
}

\author{
Maharja Jathi Perkasa \\ Magister Hukum Fakultas Hukum Universitas Hang Tuah Surabaya \\ Jl. Arief Rahman Hakim No. 150 Surabaya, Jawa Timur, 60117, (031) 5945864 \\ Email : maharjajp@gmail.com
}

\begin{abstract}
The hospital is a health service that contained risks of occupational health and safety for The hospital is a health service that contained risks of occupational health and safety for its medical personnel, so the need for hospital occupational health and safety (K3RS) project to avoid those risks. An organization such as committee needed to ensure optimal K3RS management. This research formulation of the problem are the legal responsibility of the hospital to the medical personnel for $K 3$ due to medical services in the hospital and the legal consequence of the absence of the K3RS Committee. This reasearch used normative juridical with statue approach and conseptual approach. The result showed that the hospital is responsible for problems in the scope of K3RS, responsibility related to the obligations set by the government and legal responsibility in carrying out the regulations. The result was, if the hospital did not formed an K3RS committee, they have to be legally responsible, for both criminal and civil law. Since hospital held responsibility to form a K3RS committee. According to the regulation from Hospital Accreditation Committee (KARS), director of the hospital held the responbility to fulfill this requirement.
\end{abstract}

Key words: Medical Personnel, Occupational Safety and Health.

\begin{abstract}
ABSTRAK
Rumah sakit merupakan fasilitas pelayanan kesehatan yang memiliki resiko terhadap keselamatan dan kesehatan kerja, maka diperlukan upaya pengendalian keselamatan dan kesehatan kerja rumah sakit (K3RS) untuk menghindari berbagai resiko. Untuk dapat terselenggaranya K3RS yang optimal diperlukan organisasi berbentuk komite. Rumusan masalah adalah tanggung jawab hukum rumah sakit kepada tenaga medis terhadap K3 akibat pelayanan medis di rumah sakit dan akibat hukum tidak terbentuknya Komite K3RS. Penelitian menggunakan tipe yuridis normatif dengan pendekatan perundang-undangan dan pendekatan konseptual. Hasil penelitian diketahui bahwa rumah sakit bertanggung jawab bila terjadi permasalahan dalam lingkup K3RS, tanggung jawab berhubungan dengan kewajiban yang ditetapkan pemerintah dan tanggung jawab hukum dalam menjalankan perundang-undangan. Serta didapatkan hasil, bila rumah sakit tidak membentuk komite K3RS, maka harus bertanggung jawab secara hukum, baik pidana maupun perdata. Karena pembentukan komite K3RS merupakan tanggung jawab rumah sakit. Berdasarkan ketentuan Komisi Akreditasi Rumah Sakit, direktur bertanggung jawab untuk merencanakan dan memenuhi persyaratan tersebut.
\end{abstract}

Kata kunci : Tenaga Medis, Keselamatan dan Kesehatan Kerja.

\section{PENDAHULUAN}

Kesehatan merupakan kebutuhan dasar serta menjadi hak asasi manusia yang diwujudkan dengan memberikan berbagai upaya kesehatan melalui penyelenggaraan pembangunan kesehatan. Sebagai upaya memenuhi aspek kesehatan dibutuhkan tenaga kesehatan guna meningkatkan kualitas 
pelayanan kepada masyarakat agar terwujud derajat kesehatan yang setinggi-tingginya sesuai dengan cita-cita bangsa Indonesia.

Tenaga kesehatan merupakan unsur yang strategis ataupun utama dalam mewujudkan pelayanan kesehatan yang optimal, aman, tertib dan profesional, yang berlangsung setiap waktu dan berkesinambungan. ${ }^{1}$

Tenaga Kesehatan terdiri dari berbagai macam sesuai yang dijelaskan dalam Pasal 11 ayat (1) dan ayat (2) Undang-Undang Nomor 36 Tahun 2014 Tentang Tenaga Kesehatan menjabarkan bahwa jenis tenaga kesehatan yang termasuk dalam kelompok tenaga medis sebagaimana dimaksud pada ayat (1) huruf a terdiri atas dokter, dokter gigi, dokter spesialis, dan dokter gigi spesialis.

Dalam menjalankan profesinya tenaga medis menyelenggarakan upaya kesehatan pada fasilitas pelayanan kesehatan, salah satunya di rumah sakit yang terdiri dari berbagai tenaga medis, tenaga kesehatan, maupun tenaga non kesehatan dengan bermacam-macam keahlian serta keilmuannya.

Rumah sakit merupakan organisasi yang unik dan kompleks. Dikatakan unik karena terdapat proses menghasilkan jasa perhotelan sekaligus jasa medik kepada pasien yang melakukan rawat inap maupun rawat jalan.

Sedangkan dikatakan kompleks karena rumah sakit merupakan suatu organisasi padat karya dengan latar belakang pendidikan yang berbeda-beda serta didalamnya terdapat berbagai macam fasilitas pengobatan dan berbagai macam peralatan. ${ }^{2}$

Berdasarkan Peraturan Menteri Kesehatan $\begin{array}{lll}\text { Republik } & \text { Indonesia }\end{array}$ 1204/Menkes/SK/X/2004 Tentang Persyaratan Kesehatan Lingkungan Rumah Sakit menyatakan bahwa Rumah sakit merupakan sarana pelayanan kesehatan, tempat berkumpulnya orang sakit maupun orang sehat, atau dapat menjadi tempat penularan penyakit serta memungkinkan terjadinya pencemaran lingkungan dan gangguan kesehatan.

Rumah sakit bergerak dibidang pelayanan jasa kesehatan yang mempunyai beragam persoalan tenaga kerja yang rumit dengan berbagai risiko terkena penyakit akibat kerja bahkan kecelakaan akibat kerja sesuai jenis pekerjaannya sehingga berkewajiban menerapkan upaya pembinaan keselamatan dan kesehatan kerja rumah sakit $(\mathrm{K} 3 \mathrm{RS}) .^{3}$

\footnotetext{
${ }^{1}$ Pusat Penelitian Dan Pengembangan Sistem Hukum Nasional, (2011), Laporan Akhir Tim Pengkajian Hukum Tentang Hak dan Kewajiban Tenaga Kesehatan, Jakarta; Badan Pembinaan Hukum Nasional Kementerian Hukum dan Hak Asasi Manusia Republik Indonesia. Hlm. 1.

${ }^{2}$ Enda, F, dan Supriyanto, S, (2019), Manajemen Rumah Sakit, Sidoarjo; Zifatama Jawara. Hlm. 23.

${ }^{3}$ Putri, S, et.al., (2018, Juni), Pelaksanaan dan keselamatan Kesehatan Kerja Terhadap Kejadian Kecelakaan Kerja Perawat Rumah Sakit, Jurnal Endurance, Volume 2 Nomor 3. Hlm. 271-277.
} 
Salah satu resiko yang timbul dapat terjadi pada tenaga medis ketika melakukan pelayanan medis, maka diperlukanlah pengendalian serta manajemen keselamatan dan kesehatan kerja yang bertujuan untuk menghindari berbagai macam resiko yang ada.

Selain itu rumah sakit juga dituntut untuk mampu melaksanakan pelayanan medis terkait dengan adanya suatu wabah penyakit maupun adanya kejadian luar biasa (KLB).

Keadaan tersebut akan berpengaruh terhadap situasi dan kondisi rumah sakit, terutama bagi tenaga medis yang rentan terhadap penularan penyakit dari suatu wabah yang ditangani. Sehingga K3RS sangat dibutuhkan untuk menghindari kejadian yang tidak diinginkan.

Upaya K3RS diperlukan bertujuan untuk memberikan perlindungan dan rasa aman kepada tenaga medis maupun tenaga kesehatan serta pelaksanaan upaya K3RS oleh rumah sakit juga merupakan salah satu bentuk perlindungan hukum terhadap tenaga medis.

Perlindungan atas keselamatan dan kesehatan kerja bagi tenaga medis merupakan penjabaran hak asasi manusia (HAM) dari Tuhan yang wajib dijunjung tinggi dan dilindungi oleh setiap orang, hukum, serta negara.

Sehingga dapat dikatakan juga bahwa perlindungan hukum sebagai suatu gambaran dari fungsi hukum yang memiliki konsep bahwa hukum memberikan suatu keadilan, ketertiban, kepastian, kemanfaatan dan kedamaian. ${ }^{4}$

Rumah sakit harus mampu melaksanakan dan menjalankan program keselamatan dan kesehatan kerja, karena dalam Pasal 26 ayat (2) Undang-Undang Nomor 36 Tahun 2014 tentang Tenaga Kesehatan menerangkan bahwa Pimpinan Fasilitas Pelayanan Kesehatan dan atau kepala daerah yang membawahi fasilitas pelayanan kesehatan harus mempertimbangkan pemenuhan kebutuhan sandang, pangan, papan, dan lokasi, serta keamanan dan keselamatan kerja tenaga kesehatan sesuai dengan ketentuan peraturan perundang-undangan.

Komisi Akreditasi Rumah Sakit (KARS) turut serta menunjung pelaksanaan keselamatan dan kesehatan kerja di rumah sakit dengan dibentuknya suatu standar guna menilai kepatuhan rumah sakit serta sebagai upaya peningkatan mutu rumah sakit.

Berdasarkan Pasal 40 ayat (1) UndangUndang Nomor 44 Tahun 2009 Tentang Rumah Sakit telah ditentukan bahwa dalam upaya peningkatan mutu pelayanan rumah sakit wajib dilakukan akreditasi secara berkala menimal 3 (tiga) tahun sekali.

Unsur keselamatan dan kesehatan kerja termasuk sebagai salah satu hal yang dinilai di dalam akreditasi rumah sakit yang tertuang

\footnotetext{
${ }^{4}$ Aprita, S, (2019), Perlindungan Hukum Bagi Pemegang Saham Minoritas, Kreditor, dan Karyawan Atas Akuisisi Perusahaan, Jember; Pustaka Abadi. Hlm. 37.
} 
dalam Standar Nasional Akreditasi Rumah Sakit (SNARS) edisi 1 yang berisi berbagai macam standar rumah sakit, salah satunya adalah standar tentang manajemen rumah sakit yang terdapat poin mengenai Manajemen Fasilitas dan Keselamatan (MFK).

Dalam Bab 4 Standar Nasional Akreditasi Rumah Sakit (SNARS) edisi 1 menyatakan bahwa Rumah sakit dalam kegiatannya harus menyediakan fasilitas yang aman, berfungsi, dan suportif bagi pasien, keluarga, staf, dan pengunjung.

Untuk mencapai tujuan tersebut fasilitas fisik, peralatan medis, dan peralatan lainnya harus dikelola secara efektif. Secara khusus, manajemen harus berupaya keras mengurangi dan mengendalikan bahaya dan risiko, mencegah kecelakaan dan cidera, dan memelihara kondisi aman. ${ }^{5}$

Pemenuhan terhadap aspek keselamatan dan kesehatan kerja merupakan bentuk tanggung jawab dari rumah sakit, hal tersebut berkitan dengan tanggung jawab rumah sakit terhadap personalia yang mencakup seluruh karyawan yang bekerja di suatu rumah sakit, dan tanggung jawab terhadap sarana dan prasana di rumah sakit. ${ }^{6}$
Dalam melaksanakan pelayanan kesehatan rumah sakit harus bertanggung jawab atas segala kejadian di lingkungan rumah sakit, salah satunya mengenai tanggung jawab hukum. Prinsip tanggung jawab hukum rumah sakit adalah tanggung jawab yang dapat dibebankan kepada rumah sakit sebagai fasilitas pelayan kesehatan dalam melakukan upaya kesehatan. $^{7}$

Tanggung jawab hukum rumah sakit timbul karena adanya hak dan kewajiban dari kelompok yang menjalankan organisasi rumah sakit. Kelompok tersebut terbagi menjadi tiga, yaitu pemilik, manajemen, dan pelaksana tindakan medis. ${ }^{8}$

Tujuan penelitian ini adalah menganalisis dan mengetahui tinjauan hukum tentang tanggung jawab rumah sakit terhadap kesehatan dan keselamatan kerja tenaga medis yang bekerja di rumah sakit serta menganalisis mengenai akibat hukum tidak terbentuknya komite keselamatan dan kesehatan kerja di rumah sakit, serta diharapkan bermanfaat sebagai bahan kajian dalam menambah khasanah ilmu pengetahuan bidang hukum khususnya dalam aspek keselamatan dan kesehatan kerja di rumah sakit.

\footnotetext{
${ }^{5}$ Komisi Akreditasi Rumah Sakit, (2017), Standar Nasional Akreditasi Rumah Sakit, Jakarta; Komisi Akreditasi Rumah Sakit (KARS). Hlm. 309.

6 Triwibowo, C, (2014), Etika \& Hukum Kesehatan, Yogyakarta; Nuha Media. Hlm. 232.

${ }^{7}$ Lesmonojati, S, (2020), Pertanggungjawan Pidana Atas Perbuatan Kelalaian Pada Tindakan Medis Di Rumah Sakit, Surabaya; Scopindo Media Pustaka. Hlm. 77.

8 Ibid., Hlm. 74.
} 
Metode penelitian yang digunakan yaitu dengan jenis penelitian yuridis normatif dengan pendekatan perundang-undangan (statute approach), dan pendekatan konseptual (conceptual approach). Pendekatan perundang-undangan dilakukan dengan menelaah semua undang-undang dan regulasi yang berhubungan dengan isu hukum.

Berdasarkan latar belakang yang telah diuraikan diatas, penulis tertarik untuk mengkaji lebih dalam dan agar penelitian ini lebih terarah dibuat rumusan masalah sebagai berikut: Tanggung jawab hukum rumah sakit kepada tenaga medis terhadap keselamatan dan kesehatan kerja akibat pelayanan medis di rumah sakit. Akibat hukum tidak terbentuknya komite keselamatan dan kesehatan kerja di rumah sakit.

\section{PEMBAHASAN}

Tanggung Jawab Hukum Rumah Sakit Kepada Tenaga Medis Terhadap Keselamatan dan Kesehatan Kerja Akibat Pelayanan Medis di Rumah Sakit.

Tanggung jawab muncul dari adanya aturan hukum yang memberikan kewajiban kepada subyek hukum dengan ancaman sanksi apabila kewajiban tersebut tidak dilaksanakan. Tanggung jawab demikian juga dikatakan sebagai tanggung jawab hukum, karena muncul dari perintah aturan hukum atau undang-undang dan sanksi yang diberikan juga merupakan sanksi yang ditetapkan oleh undang-undang, oleh karena itu pertanggungjawaban yang dilakukan oleh subyek hukum merupakan tanggung jawab hukum. ${ }^{9}$

Tanggung jawab hukum muncul sebab adanya suatu aturan hukum yang memberikan kewajiban kepada suatu subyek hukum dengan ancaman sanksi bila kewajiban tersebut tidak terlaksana. ${ }^{10}$

Akibat adanya kewajiban yang tidak dipenuhi oleh salah satu pihak yang melakukan perjanjian, sehingga membuat pihak yang lain mengalami kerugian akibat haknya tidak dapat dipenuhi oleh salah satu pihak tersebut.

Organisasi rumah sakit disusun dengan tujuan untuk mencapai visi misi dengan menjalankan tata kelola perusahaan yang baik (good corporate gorvernance) dan tata kelola klinis yang baik (good clinical governance).

Ketetentuan tersebut diharapkan rumah sakit dapat melaksanakan penyelenggaraan dengan baik dan bertanggung jawab, karena rumah sakit merupakan subyek hukum (badan hukum privat ataupun publik) yang memiliki wewenang untuk melaksanakan perbuatan

\footnotetext{
9 Akfa, V, (2017, Januari), Pertanggungjawaban Hukum dan Perlindungan Hukum bagi Notaris dalam Membuat Party Acte, Lex Renaissance, Nomor 1 Volume 2, Hlm. 162-176.

10 Ayu, N, (2020), Tanggung Jawab Hukum Dalam Penolakan Pasien Jaminan Kesehatan Nasional, Surabaya; Scopindo Media Pustaka. Hlm. 7.
} 
hukum serta perbuatan tersebut harus dapat dipertanggungjawabkan secara hukum. ${ }^{11}$

Rumah sakit sebagai institusi yang membawahi tenaga medis dan tenaga kesehatan untuk melakukan pelayanan kesehatan, bertanggung jawab atas segala peristiwa yang terjadi di dalam rumah sakit, salah satu diantaranya mengenai tanggung jawab hukum rumah sakit.

Mengenai tanggung jawab rumah sakit telah diatur dalam Pasal 46 Undang-Undang Nomor 44 Tahun 2009 Tentang Rumah Sakit yang menjelaskan bahwa Rumah Sakit bertanggung jawab secara hukum terhadap semua kerugian yang ditimbulkan atas kelalaian yang dilakukan oleh tenaga kesehatan di rumah sakit.

Prinsip tanggung jawab hukum rumah sakit adalah tanggung jawab yang dapat dibebankan kepada rumah sakit sebagai fasilitas pelayan kesehatan dalam melakukan upaya kesehatan. Tanggung jawab tersebut meliputi: ${ }^{12}$

a. Tanggung jawab hukum yang berhubungan dengan hak pasien

b. Tanggung jawab hukum yang berhubungan dengan kewajiban yang telah ditetapkan oleh pemerintah

c. Tanggung jawab hukum yang berhubungan dengan tugas menjalankan perundang-undangan.
Selain itu, Guwandi menjabarkan bahwa rumah sakit memiliki beberapa bidang dalam hal pertanggungjawaban, diantaranya sebagai berikut: ${ }^{13}$

a. Tanggung Jawab Terhadap Personalia

Dahulu hubungan ini bersifat universal dan negara Indonesia masih memberlakukan berdasarkan 1366 jo 1365 jo 1367 Kitab Undang Undang Hukum Perdata Pasal. Didalam tanggung jawab ini termasuk seluruh karyawan yang bekerja di suatu rumah sakit.

b. Tanggung Jawab Profesional Terhadap Mutu Pengobatan Atau Perawatan

Tingkat pemberian pelayanan kesehatan baik oleh dokter maupun perawat dan tenaga kesehatan lainnya harus berdasarkan ukuran standar profesi. Maka secara yuridis suatu rumah sakit memiliki tanggung jawab apabila ada pemberian pelayanan "cure and care" yang tidak lazim atau dibawah standar.

c. Tanggung Jawab Terhadap Sarana dan Prasarana

Dalam tanggung jawab ini meliputi peralatan dasar perhotelan, perumahakitan, peralatan medis, dan lainlain. Serta yang terpenting adalah bahwa peralatan-peralatan tersebut harus selalu berada dalam keadaan aman dan siap pakai setiap saat.

\footnotetext{
11 Lesmonojati, S, Op. Cit., Hlm. 72.

12 Ibid., Hlm. 77.

13 Triwibowo, C, Op. Cit., Hlm. 232
} 
d. Tanggung Jawab Terhadap Keamanan Bangunan dan Perawatannya

Tanggung jawab ini meliputi bangunan yang ada di gedung rumah sakit, contohnya bila ada bangunan yang roboh hingga ada pengunjung di rumah sakit jatuh dan fraktur. Di Indonesia peraturan ini diatur dalam Pasal 1369 Kitab Undang Undang Hukum Perdata tentang tanggung jawab pemilik terhadap gedung.

Rumah sakit sebagai rechtpersoon bertanggung jawab atas seluruh pelayanan kesehatan yang dilakukan rumah sakit, sehingga harus berbadan hukum agar dapat melakukan perbuatan hukum secara sah sebagai antisipasi bila terjadi suatu permasalahan hukum, adanya tuntutan, gugatan ganti kerugian dan lain sebagainya.

Perbuatan hukum rumah sakit tersebut berkaitan dengan hak dan kewajiban secara hukum, serta hubungan dengan pihak internal maupun eksternal rumah sakit. Hubungan internal rumah sakit berkaitan dengan kepegawaian rumah sakit, sedangkan hubungan eksternal rumah sakit berkaitan dengan pihak luar rumah sakit.

Salah satu bentuk kewajiban rumah sakit adalah menjamin akan keselamatan dan kesehatan kerja pada tenaga medis, hal tersebut juga merupakan bentuk perlindungan hukum dan hak bagi tenaga medis yang telah diatur dalam peraturan perundang-undangan.

Perlindungan hukum merupakan segala upaya yang dapat menjamin kepastian hukum, sehingga dapat memberikan perlindungan hukum kepada pihak yang bersangkutan ataupun kepada pihak yang melakukan tindakan hukum. Sedangkan prinsip perlindungan hukum bagi rakyat Indonesia adalah sebagai pengakuan dan perlindungan terhadap harkat dan martabat manusia yang bersumber pada Pancasila serta prinsip hukum yang berdasarkan dari Pancasila. ${ }^{14}$

Tenaga medis sebagai unsur dalam mewujudkan pelayanan kesehatan dengan tugas melayani masyarakat sudah selayaknya mendapatkan perlindungan hukum. Salah satu perlindungan hukum terhadap tenaga medis adalah perlindungan terhadap keselamatan dan kesehatan kerja.

Aturan tersebut tercantum dalam Pasal 57 poin d Undang-Undang Nomor 36 Tahun 2014 Tentang Tenaga Kesehatan yang menjelaskan bahwa dalam praktik tenaga kesehatan Memperoleh perlindungan atas keselamatan dan kesehatan kerja, perlakuan yang sesuai dengan harkat dan martabat manusia, moral, kesusilaan, serta nilai-nilai agama.

Sehingga pihak rumah sakit harus melaksanakan ketentuan tersebut, karena merupakan salah satu faktor yang penting

\footnotetext{
14 Pangabean, H, (2018), Perlindungan Hukum Praktik Klinik Kebidanan, Yogyakarta; Deepublish. Hlm. 65.
} 
dalam terlaksananya penyelenggaraan pelayanan kesehatan. Namun bila tidak menyelenggarakan, rumah sakit juga harus siap bertanggungjawab jika terjadi suatu permasalahan dalam lingkup keselamatan dan kesehatan kerja akibat pelayanan medis terhadap tenaga medis.

Terjaminnya keselamatan dan kesehatan kerja tenaga medis di rumah sakit juga merupakan bentuk kewajiban dari rumah sakit. Bilamana rumah sakit tidak dapat melaksanakan atau menyelenggarakan upaya K3RS, maka rumah sakit harus siap bertanggungjawab bila terjadi suatu permasalahan dalam lingkup keselamatan dan kesehatan kerja akibat pelayanan medis terhadap tenaga medis.

Salah satunya adalah tanggung jawab hukum, seperti yang diketahui bahwa rumah sakit merupakan subyek hukum (badan hukum privat maupun publik) yang memiliki wewenang untuk melaksanakan perbuatan hukum serta perbuatan tersebut harus dapat dipertanggungjawabkan secara hukum. ${ }^{15}$

Tanggung jawab hukum rumah sakit timbul dari adanya hak dan kewajiban dari kelompok yang menjalankan organisasi rumah sakit. Kelompok tersebut terbagi menjadi tiga, yaitu pemilik, manajemen, dan pelaksana tindakan medis. ${ }^{16}$ Tanggung jawab dalam hukum dibedakan menjadi tiga, yaitu tanggung jawab pidana, tanggung jawab perdata, dan tanggung jawab administrasi.

\section{Akibat Hukum Tidak Terbentuknya Komite Keselamatan dan Kesehatan Kerja di Rumah Sakit}

Penyelenggaraan K3 di rumah sakit merupakan sebuah kewajiban. Bab XII Undang-Undang Nomor 36 Tahun 2009 Tentang Kesehatan telah mengatur tentang pelaksanaan upaya kesehatan dan keselamatan kerja harus diselenggarakan di semua tempat kerja yang khususnya tempat kerja yang mempunyai risiko bahaya kesehatan serta mudah terjangkit penyakit serta pengelola tempat kerja berkewajiban untuk menjamin dan bertanggung jawab atas keselamatan dan kesehatan kerja. Dalam hal ini rumah sakit dapat dikatakan sebagai tempat kerja bagi tenaga medis.

Begitu juga pada tahun 2018, seluruh rumah sakit di Indonesia telah memasuki era Standar Nasional Akreditasi Rumah Sakit (SNARS) edisi 1. Salah satu penilaiannya adalah mengenai Manajemen Fasilitas dan Keselamatan (MFK). Standar penilaian ini berisi tentang jaminan keselamatan dan keamanan bagi seluruh penghuni rumah sakit yang meliputi staf, pasien dan pengunjung.

Dengan adanya parameter tersebut rumah sakit diharapkan untuk membentuk organisasi rumah sakit berupa komite atau instalasi keselamatan dan kesehatan kerja rumah sakit

15 Lesmonojati, S, Op. Cit., Hlm. 72.

16 Ibid., Hlm. 74. 
(K3RS) untuk menjamin keselamatan dan kesehatan kerja.

Pada Bab MFK SNARS edisi 1 menjelaskan bahwa semua rumah sakit tanpa memperhatikan kelas rumah sakit dan sumber daya wajib mematuhi peraturan perundangundangan tersebut, yaitu menyediakan bangunan dan fasilitas yang aman sebagai tanggung jawab kepada pasien, keluarga, pengunjung, dan staf/pegawai rumah sakit. Bila rumah sakit dianggap tidak memenuhi syarat maka direktur rumah sakit yang bertanggung jawab merencanakan dan memenuhi persyaratan tersebut dalam kurun waktu yang ditentukan. ${ }^{17}$

Untuk dapat mewujudkan pelaksanaan upaya K3RS tersebut, maka diperlukan suatu tindakan penunjang yaitu dengan cara membentuk organisasi yang profesional serta memiliki prosedur kerja yang tepat guna merencanakan dan menjalankan K3RS. Ketentuan tersebut telah diatur dalam beberapa peraturan maupun keputusan Menteri Kesehatan yang berhubungan dengan K3 rumah sakit.

Dalam Bab II Peraturan Menteri Kesehatan Nomor 66 Tahun 2016 Tentang Keselamatan dan Kesehatan Kerja Rumah Sakit menerangkan bahwa Untuk terselenggaranya K3RS secara optimal, efektif, efesien dan berkesinambungan, rumah sakit membentuk atau menunjuk satu unit kerja fungsional yang mempunyai

tanggung

jawab menyelenggarakan K3RS.

Berdasarkan Pasal 6 ayat (2) Peraturan Presiden Republik Indonesia Nomor 77 Tahun 2015 Tentang Pedoman Organisasi Rumah Sakit (selanjutnya disebut Perpres Pedoman Organiasasi RS) menjelaskan tentang unsur organisasi rumah sakit dapat berupa direktorat, departemen, divisi, instalasi, unit kerja, komite dan/atau satuan sesuai dengan kebutuhan dan beban kerja rumah sakit.

Selanjutnya dijelaskan pada Pasal 4 Perpres Pedoman Organisasi RS bahwa organisasi rumah sakit disesuaikan dengan besarnya kegiatan dan beban kerja rumah sakit. Serta struktur organisasi rumah sakit harus membagi habis seluruh tugas dan fungsi rumah sakit.

Wujud komitmen menyelenggarakan K3RS, diawali dengan direktur rumah sakit membentuk komite K3 rumah sakit yang mana ketua komitenya adalah direktur atau satu level dibawahnya. Komite K3 rumah sakit bertugas membuat kebijakan K3RS dan program-program K3 lainnya.

Pembentukan Komite K3RS disertai dengan surat keputusan direktur rumah sakit yang terdiri dari dua jenis surat keputusan yang perlu dikeluarkan oleh direktur, yaitu SK Pembentukan Organisasi Komite K3, dan SK

\footnotetext{
17 Komisi Akreditasi Rumah Sakit, Op. Cit., Hlm. 310-311.
} 
penunjukan/penugasan untuk semua anggota komite K3. ${ }^{18}$

Dari beberapa paparan yang telah dijelaskan, sudah sepatutnya setiap rumah sakit membentuk komite ataupun istalasi khusus K3 yang benar-benar berdiri sendiri serta tidak bercampur dengan bidang lainnya.

Ketentuan tersebut merupakan suatu tanggung jawab rumah sakit yang meliputi tanggung jawab hukum yang berhubungan dengan kewajiban yang telah ditetapkan oleh pemerintah dan juga tanggung jawab hukum yang berhubungan dengan tugas menjalankan perudang-undangan.

Rumah sakit sebagai rechtpersoon bertanggung jawab atas seluruh pelayanan kesehatan yang dilakukan. Dengan adanya suatu tanggung jawab hukum tersebut, bilamana rumah sakit tidak melaksanakan ketentuan yang menjadi kewajibannya dalam hal ini pembentukan komite K3RS, maka rumah sakit harus mempertanggungjawaban secara hukum baik secara pidana ataupun perdata karena dianggap telah lalai dalam melaksanakan tugasnya.

Tanggung jawab hukum yang timbul berupa tanggung jawab pidana dan tanggung jawab perdata. Pertanggungjawaban pidana dalam hukum pidana merupakan konsep sentral yang dikenal dengan ajaran kesalahan. Kesalahan dalam arti sempit dapat berbentuk sengaja (opzet) atau lalai (culpa). ${ }^{19}$

Pertanggungjawaban pidana merupakan perwujudan terpenuhinya beberapa unsur tindakan pidana, yaitu adanya sifat melawan hukum (bertentangan dengan undang-undang) dan adanya kesalahan dari pembuat, yaitu dari orang atau manusia. ${ }^{20}$

Aspek kesalahan (sculd) merupakan asas fundamental dalam hukum pidana dalam menentukan dapat dipidanya pembuat suatu kesalahan (culpabilitas). Kesalahan diartikan secara luas yaitu meliputi kemampuan untuk bertanggung jawab (toerekeningsvaatbaarheid), kesengajaan, dan tidak adanya alasan pemaaf. ${ }^{21}$

Kesalahan dalam hukum pidana menjadi faktor utama atau merupakan faktor yang menentukan adanya suatu pertanggung jawaban pidana, yang meliputi kesengajaan dan kelalaian. Hal tersebut memiliki arti bahwa sikap kalbu (mens rea) dalam hukum pidana terdiri dari kesengajaan atau kealpaan, kepadanya harus dapat dibuktikan keberadaannya untuk dapat dimintai

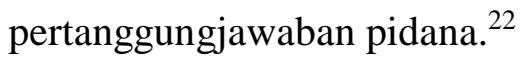

18 Ismail, A, (5 April 2018), Penerapan Kesehatan dan keselamatan Kerja Rumah Sakit (K3RS), Diakses Maret 9 Maret 2020, HSP Academy: http://healthsafetyprotection.com/penerapan-kesehatan-dan-keselamatan-kerjarumah-sakit-k3 rs/\#page-content.

19 Ishaq, (2020), Hukum Pidana, Depok; Rajawali Pers. Hlm. 93.

${ }^{20}$ Rusianto, A, (2016), Tindak Pidana \& Pertanggungjawaban Pidana (Tinjauan Kritis Melalui Konsistensi Antara Asas, Teori, dan Penerapannya), Jakarta; Kencana. Hlm. 28.

21 Ishaq, Op. Cit., Hlm. 95.

22 Sjawie, H, F, (2015), Pertanggungjawaban Pidana Korporasi Pada Tindak Pidana Korupsi, Jakarta; Kencana. Hlm. 13-14. 
Dalam peraturan hukum di Indonesia, prinsip pertanggungjawaban pidana telah diatur dalam Kitab Undang-Undang Hukum Pidana, dalam kitab tersebut menjelaskan prinsip tentang siapa yang berbuat maka dia yang bertanggung jawab.

Ketentuan tersebut diatur dalam Pasal 2 Kitab Undang Undang Hukum Pidana yang berbuyi "Ketentuan pidana dalam perundangundangan dangan Indonesia diterapkan bagi setiap orang yang melakukan sesuatu tindak pidana di Indonesia".

Pada Bab XXI Kitab Undang Undang Hukum Pidana terdapat pasal-pasal yang telah mengatur mengenai kesalahan ataupun kealpaan seseorang yang dapat menyebabkan orang lain luka-luka bahkan meninggal dunia, serta pasal tersebut juga mengatur sanksi yang berguna sebagai pertanggungjawaban tindakan pidana atas perbuatan yang dilakukannya. Adapun pasal tersebut sebagai berikut :

a. Pasal 359 Kitab Undang Undang Hukum Pidana menjelaskan bahwa Barang siapa karena kesalahannya (kealpaannya) menyebabkan orang lain mati, diancam dengan pidana penjara paling lama lima tahun atau pidana kurungan paling lama satu tahun.

b. Pasal 360 Kitab Undang Undang Hukum Pidana ayat (1) menjelaskan Barang siapa karena kesalahannya (kealpaannya) menyebabkan orang lain mendapat lukaluka berat, diancam dengan pidana penjara paling lama lima tahun atau pidana kurungan paling lama satu tahun.

c. Pasal 360 Kitab Undang Undang Hukum Pidana ayat (2) menjabarkan bahwa Barang siapa karena kesalahannya (kealpaannya) menyebabkan orang lain luka-luka sedemikian rupa sehingga timbul penyakit atau halangan menjalankan pekerjaan jabatan atau pencarian selama waktu tertentu, diancam dengan pidana penjara paling lama sembilan bulan atau pidana kurungan paling lama enam bulan atau pidana denda paling tinggi empat ribu lima ratus rupiah.

d. Pasal 361, 359 Kitab Undang Undang Hukum Pidana menjelaskan bahwa jika kejahatan yang diterangkan dalam bab ini dilakukan dalam menjalankan suatu jabatan atau pencarian, maka pidana ditambah dengan sepertiga dan yang bersalah dapat dicabut haknya untuk menjalankanpencarian dalam mana dilakukan kejahatan dan hakim dapat memerintahkan supaya putusannya diumumkan.

Sedangkan Tanggung jawab hukum perdata merupakan tanggung jawab seseorang terhadap perbuatan yang melawan hukum. Perbuatan melawan hukum memiliki ruang lingkup yang lebih luas dibandingkan dengan perbuatan pidana. Pertanggungjawaban perdata perlu dibuktikan dengan adanya kemungkinan-kemungkinan sebagai bentuk dari aspek adanya kerugian, sedangkan pada 
pertanggungjawaban pidana dari bentuk aspek reasonable doubt. ${ }^{23}$

Pada hakekatnya tanggung jawab hukum dalam ruang lingkup hukum perdata ada dua macam, yaitu bentuk pertanggungjawaban hukum yang disebabkan karena wanprestasi yaitu perbuatan tidak memenuhi prestasi atau kewajibannya, serta pertanggung jawaban akibat perbuatan melanggar hukum. ${ }^{24}$

Seseorang dapat diminta pertanggung jawaban hukum jika melakukan kelalaian ataupun kesalahan yang dapat mengakibatkan kerugian pada orang lain, sehingga seseorang yang mendapat kerugian berhak untuk menggugat ganti rugi.

Dalam hukum di Indonesia, tanggung jawab dalam hukum perdata berkaitan dengan aturan-aturan ataupun pasal-pasal dalam Kitab Undang-Undang Hukum Perdata. Salah satunya tentang kesalahan ataupun kelalaian yang telah diatur dalam pasal-pasal sebagai berikut:

a. Pasal 1365 Kitab Undang Undang Hukum Perdata disebutkan bahwa Setiap perbuatan yang melanggar hukum dan membawa kerugian kepada orang lain, mewajibkan orang yang menimbulkan kerugian itu karena kesalahannya untuk menggantikan kerugian tersebut.

b. Pasal 1366 Kitab Undang Undang Hukum Perdata menjelaskan bahwa Setiap orang bertanggung-jawab tidak saja untuk kerugian yang disebabkan karena perbuatannya, tetapi juga untuk kerugian yang disebabkan karena kelalaian atau kurang hati-hatinya.

c. Pasal 1367 Kitab Undang Undang Hukum Perdata, menyebutkan bahwa "Seorang tidak saja bertanggung-jawab untuk kerugian yang disebabkan karena perbuatannya sendiri, tetapi juga untuk kerugian yang disebabkan karena perbuatan orang-orang yang menjadi tanggungannya, atau disebabkan oleh orang-orang yang berada di bawah pengawasannya.

Dijelaskan bahwa pertanggungjawabannya selain terletak pada pelakunya sendiri juga dapat dialihkan pada pihak lain atau kepada negara, tergantung siapa yang melakukannya.

Namun mengenai ganti rugi, Kitab Undang Undang Hukum Perdata tidak dengan tegas atau bahkan tidak mengatur secara rinci mengenai ganti rugi ataupun tentang salah satu aspek dari ganti rugi, maka hakim memiliki kebebasan untuk menerapkan ganti rugi tersebut sesuai dengan asas kepatutan hukum, yang mana sejauh hal tersebut memang dimintakan oleh pihak penggugat.

Sehingga dari beberapa pasal tersebut, maka dapat ditarik beberapa unsur untuk

23 Lesmonojati, S, Op. Cit., Hlm. 8-9.

${ }^{24}$ Lossa, C, (2016, Juni), Tanggung Jawab Hukum RSUD Tora Belo Kabupaten Sigi Terhadap Pelayanan Kesehatan Masyarakat, eJurnal Katalogis, Volume 4 Nomor 6, Hlm. 122-133. 
dapat mempertanggungjawabkan secara perdata, diantaranya adalah adanya perbuatan melawan hukum, adanya kesalahan, adanya hubungan sebab akibat antara kerugian dan perbuatan, serta adanya kerugian.

\section{KESIMPULAN}

1. Terjaminnya akan keselamatan dan kesehatan kerja tenaga medis di rumah sakit merupakan kewajiban dari rumah sakit. Bilamana rumah sakit tidak dapat melaksanakan atau menyelenggarakan upaya K3RS, rumah sakit harus siap bertanggungjawab bila terjadi permasalahan dalam lingkup keselamatan dan kesehatan kerja akibat pelayanan medis terhadap tenaga medis.

Tanggung jawab hukum tersebut berhubungan dengan kewajiban yang telah ditetapkan oleh pemerintah dan tanggung jawab hukum dalam tugas menjalankan perundang-undangan. Pertanggung jawaban hukum rumah sakit dapat berupa tanggung jawab pidana, tanggung jawab perdata, dan tanggung jawab administrasi.

2. Jika suatu rumah sakit tidak terbentuk Komite Keselamatan dan Kesehatan Kerja Rumah Sakit (K3RS), maka rumah sakit harus bertanggung jawab secara hukum, baik secara pidana yang diatur dalam Pasal 359 dan Pasal 360 Kitab Undang-Undang Hukum Pidana ataupun secara perdata yang diatur pada Pasal 1365, 1366, dan
1367 Kitab Undang Undang Hukum Perdata.

Karena pembentukan komite K3RS merupakan suatu bentuk tanggung jawab rumah sakit. Serta berdasar ketentuan Komisi Akreditasi Rumah Sakit, bila rumah sakit tidak memenuhi syarat, maka direktur bertanggung jawab untuk merencanakan dan memenuhi persyaratan tersebut.

\section{SARAN}

1. Dari peraturan mengenai keselamatan dan kesehatan kerja bagi tenaga medis yang telah ada, sudah sepatutnya ketentuan tersebut menjadi acuan dan dipatuhi oleh rumah sakit dalam memberikan perlindungan serta pertanggungjawaban hukum bila terjadi permasalahan dalam lingkup keselamatan dan kesehatan kerja akibat pelayanan medis.

2. Ketentuan mengenai sanksi bagi rumah sakit yang tidak membentuk komite ataupun instalasi keselamatan dan kesehatan kerja di rumah sakit telah diatur dalam aturan hukum lex generalis. Sehingga perlu diatur lebih lanjut mengenai sanksi tersebut dalam bentuk aturan hukum lex spesialis, yang dapat diatur dalam bentuk undang-undang, peraturan menteri kesehatan, ataupun diatur dalam peraturan daerah. Pembentukan komite dan instalasi keselamatan dan kesehatan kerja di rumah sakit merupakan salah satu bentuk 
perwujudan dalam melaksanakan upaya K3RS.

\section{DAFTAR PUSTAKA}

\section{Peraturan Perundang-Undangan}

Kitab Undang-Undang Hukum Pidana (KITAB UNDANG UNDANG HUKUM PIDANA)

Kitab Undang-Undang Hukum Perdata (Burgerlijk Wetboek voor Indonesie)

Undang-Undang Nomor 36 Tahun 2009

Tentang Kesehatan

Undang-Undang Nomor 44 Tahun 2009

Tentang Rumah Sakit

Undang-Undang Nomor 36 Tahun 2014

Tentang Tenaga Kesehatan

Peraturan Presiden Republik Indonesia

Nomor 77 Tahun 2015 Tentang

Pedoman Organisasi Rumah Sakit

Peraturan Menteri Kesehatan Republik

Indonesia

No.

1204/Menkes/SK/X/2004

Tentang

Persyaratan Kesehatan Lingkungan

Rumah Sakit

Peraturan Menteri Kesehatan Nomor 66

Tahun 2016 Tentang Keselamatan dan

Kesehatan Kerja Rumah Sakit

\section{Buku}

Aprita, S. (2019). Perlindungan Hukum Bagi

Pemegang Saham Minoritas,

Kreditor, dan Karyawan Atas Akuisisi

Perusahaan, Jember: Pustaka Abadi.

Ayu, N. (2020). Tanggung Jawab Hukum

Dalam Penolakan Pasien Jaminan

Kesehatan Nasional, Surabaya:

Scopindo Media Pustaka.

Enda, F. dan Supriyanto, S. (2019).

Manajemen Rumah Sakit, Sidoarjo:

Zifatama Jawara.

Ishaq. (2020). Hukum Pidana, Depok:

Rajawali Pers.

Komisi Akreditasi Rumah Sakit. (2017),

Standar Nasional Akreditasi Rumah
Sakit, Jakarta: Komisi Akreditasi Rumah Sakit (KARS).

Lesmonojati, S. (2020) Pertanggungjawan

Pidana Atas Perbuatan Kelalaian

Pada Tindakan Medis Di Rumah Sakit, Surabaya: Scopindo Media Pustaka.

Pangabean, H. (2018). Perlindungan Hukum

Praktik Klinik Kebidanan,

Yogyakarta: Deepublish.

Pusat Penelitian Dan Pengembangan Sistem Hukum Nasional, (2011). Laporan Akhir Tim Pengkajian Hukum Tentang Hak dan Kewajiban Tenaga Kesehatan, Jakarta: Badan Pembinaan Hukum Nasional Kementerian Hukum Dan Hak Asasi Manusia Republik Indonesia.

Rusianto, A. (2016). Tindak Pidana \& Pertanggungjawaban Pidana (Tinjauan Kritis Melalui Konsistensi Antara Asas, Teori, dan Penerapannya), Jakarta: Kencana.

Sjawie, H, S. (2015). Pertanggungjawaban Pidana Korporasi Pada Tindak Pidana Korupsi, Jakarta: Kencana.

Triwibowo, C. (2014). Etika \& Hukum Kesehatan, Yogyakarta: Nuha Media. Wardiono, K, et al. (2018) Buku Ajar Hukum Perdata, Surakarta: Muhammadiyah University Press.

\section{Jurnal}

Akfa, V. (2017, Januari), Pertanggungjawaban Hukum dan Perlindungan Hukum bagi Notaris dalam Membuat Party Acte, Lex Renaissance, Volume 2 Nomor 1.

Lossa, C. (2016, Juni), Tanggung Jawab Hukum RSUD Tora Belo Kabupaten Sigi Terhadap Pelayanan Kesehatan Masyarakat, eJurnal Katalogis, Volume 4 Nomor 6.

Putri, S, et.al., (2018, Juni), Pelaksanaan dan keselamatan Kesehatan Kerja Terhadap Kejadian Kecelakaan Kerja Perawat 
Rumah Sakit, Jurnal Endurance, Volume 2 Nomor 3.

\section{Internet}

Alfajri Ismail, A, 2018, (2018, 5, April), Penerapan Kesehatan dan keselamatan
Kerja Rumah Sakit (K3RS), Diakses pada Maret, 9, 2020, HSP Academy: http://healthsafetyprotection.com/penera pan-kesehatan-dan-keselamatan-kerjarumah-sakit-k3 rs/\#page-content. 